\title{
Peran Komisi Pemilihan Umum (KPU) Kabupaten Bone Dalam Pemenuhan Hak Politik Penyandang Disabilitas Di Pemilihan Umum Tahun 2019
}

\author{
Adi Akmal \\ Institut Agama Islam Negeri (IAIN) Bone \\ adiakmalhtngmail.com
}

\begin{abstract}
Abstrak
Penelitian ini bertujuan untuk mengetahui peran Komisi Pemilihan Umum (KPU) Kabupaten Bone dalam pemenuhan hak politik penyandang disabilitas dan untuk mengetahui kendala yang dihadapi Komisi Pemilihan Umum (KPU) Kabupaten Bone dalam pemenuhan hak pilih penyandang disabilitas di pemilihan umum tahun 2019. Masalah ini dianalisis dengan pendekatan Yuridis Normatif dan Yuridis Empiris dan dibahas dengan menggunakan Metode Kualitatif. Hasil penelitian menunjukkan bahwa peran Komisi Pemilihan Umum (KPU) Kabupaten Bone tersebut telah sesuai dengan Undang-Undang Nomor 7 Tahun 2017 tentang Pemilihan Umum dan pemenuhan hak-hak politik Penyandang Disabilitas yang telah diberikan sesuai dengan Undang-Undang Nomor 8 Tahun 2016 tentang Penyandang Disabilitas, meskipun peran dan pemenuhan hak-hak politik penyandang disabilitas dalam pemilihan umum tersebut belum dapat dilakukan secara maksimal.
\end{abstract}

\section{Kata Kunci : Peran Komisi Pemilihan Umum dan Pemenuhan Hak Politik Penyandang Disabilitas}

\section{PENDAHULUAN}

Pasal 1 ayat (3) Undang-Undang Dasar Negara Republik Indonesia Tahun 1945 disebutkan secara tegas bahwa Negara Republik Indonesia adalah negara hukum $^{205}$, kemudian di dalam penjelasan Undang-Undang Dasar Tahun 1945

\footnotetext{
${ }^{205}$ Republik Indonesia. Undang-Undang Dasar Tahun 1945, Pasal 1, ayat (3).
} 
disebutkan bahwa Negara Republik Indonesia adalah berdasar atas hukum (Rechtsstaat).

Negara hukum pada prinsipnya adalah negara yang menjunjung tinggi supremasi hukum, dimana konstitusi dan peraturan hukum atau regulasi menjadi acuan nyata dalam kehidupan berbangsa dan bernegara.Sejatinya negara hukum sangat melindungi Hak Asasi Manusia (HAM).Indonesia sebagai negara hukum diharuskan menjaga dan melindungi HAM yang sudah diatur secara tegas dalam Pasal 28 A-J Undang-Undang Dasar Tahun 1945. 206

Hak Asasi Manusia dalam Islam mengandung prinsip-prinsip dasar tentang kebebasan, persamaan, dan penghormatan terhadap sesama manusia.Persamaan artinya Islam memandang semua manusia sama dan mempunyai kedudukan sama. ${ }^{207}$ Allah berfirman dalam QS al-Hujurat/49: 13.

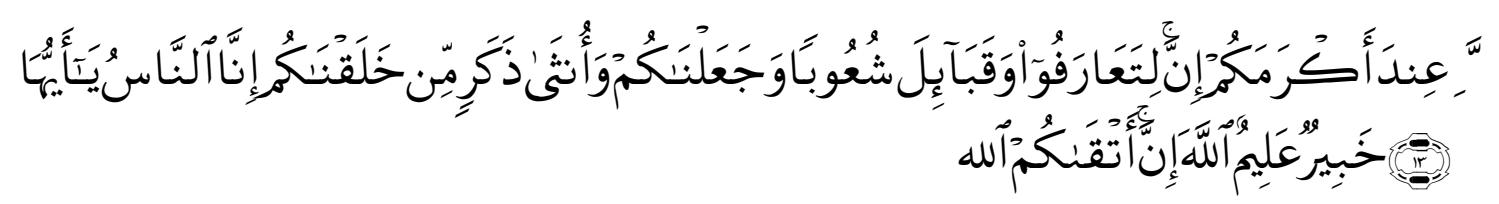

Terjemahnya:

"Hai manusia, Sesungguhnya kami menciptakan kamu dari seorang laki-laki dan seorang perempuan dan menjadikan kamu berbangsabangsa dan bersuku-suku supaya kamu saling kenal-mengenal. Sesungguhnya orang yang paling mulia diantara kamu disisi Allah ialah orang yang paling taqwa diantara kamu. Sesungguhnya Allah Maha mengetahui lagi Maha Mengenal". 208

${ }^{206}$ Moh. Syaiful Rahman dan Rosita Indaryati, "Hak Pilih Penyandang Disabilitas dalam Pemilihan Umum di Indonesia”, Jurnal Lentera Hukum, Vol. 6, No.1, 28 April 2019. hlm. 152.

${ }^{207}$ T. Muhammad Hasby Ash shiddieqh, Islam dan Hak Asasi Manusia.(Semarang: PT. Pustaka Rizki Putra, 1999), h. 23.

${ }^{208}$ Al-Jumanatul Ali, Al-Quran dan Terjemahan (Jakarta: Departemen Agama Republik Indonesia, 2006), h. 518. 
Konsep HAM dalam Islam bersumber pada al-Qur'an dan as-Sunnah.Islam tidak mengenal paham diskriminasi atau perbedaan rasional, ideologi, agama, dan suku.Manusia di mata Allah SWT adalah sama, yang membedakan hanyalah takwa yang dimiliki oleh manusia tersebut. ${ }^{209}$

Hak Asasi Manusia (HAM) merupakanhakdasar yang dimiliki oleh manusia yang dibawanya sejak lahir bahkan dari keberadaannya sebagai anugerah Tuhan Yang Maha Esa.HAM memiliki lingkup yang sangat luas. Garis besar hak-hak yang terangkum dalam HAM diantaranya adalah hakasasi politik (Political rights).Berkaitandengan politik, Undang-Undang Dasar 1945 sebagai konstitusi Negara Republik Indonesia telah mengamanatkan bahwa "Segala warga negara bersamaan kedudukannya di dalam hukum dan pemerintahan dan wajib menjunjung hukum dan pemerintahan itu dengan tidak ada kecualinya". ${ }^{210}$

Politik dalam perspektif ulama fikhi adalah satu bentuk interaksi yang dilakukan oleh seorang pemimping secara evulusioner untuk mencapai satu maslahah sekaligus tidak diperkuat oleh sebuah teks atau dalil agama.Dapat pula diartikan sebagai satu bentuk pengaturan yang dilakuan oleh pemerintah di tengah-tengah komunitas masyarakat plural, baik yang terkait dengan masalah keagamaan maupun terkait dengan masalah kehidupan dunia semata demi terciptanya suasana yang lebih baik dan egalitarian.Dari penegasan tersebut dapat dipahami bahwa poitik di dalam Islam dapat dimaknai sebagai system hukum yang diberlakukan untuk mengatur stabilitas negara serta membangun kesejahteraan rakyat dengan satu konsekuensi

${ }^{209}$ H. Abdul Mana, Politik Hukum : Studi Perbandingan dalam Praktik Ketatanegaraan Islam dan Sistem Hukum Barat (Ed. 1, Cet, 1; Jakarta: Prenamedia Group, 2016), h.198.

${ }^{210}$ Republik Indonesia. Undang-Undang Dasar Tahun 1945, Pasal 27, ayat (1). 
bahwa setiap kebijakan mesti dilakukan secara paradigma sehingga kontroversi dengan nilai moralitas agama. ${ }^{211}$

BangsaIndonesia menempatkan pengakuan dan jaminan HAM dalam UndangUndang Dasar Negara Republik Indonesia Tahun 1945 yang didasari oleh pemahaman bahwa HAM merupakan hak dasar yang secara kodrati melekat pada diri setiap warga negara tanpa diskriminasi, termasuk bagi para penyandang disabilitas. Tanggung jawab negara terhadap penghormatan dan pengakuan atas HAM ini terdapat dalam Pasal 28I ayat (4) Undang-Undang Dasar Negara Republik Indonesia Tahun 1945 yang menyatakan bahwa perlindungan, pemajuan, penegakan, dan pemenuhan hak asasi manusia adalah tanggung jawab negara, terutama Pemerintah. $^{212}$

Setiap penyandang disabilitas mempunyai hak dan kesempatan yang sama dalam segala bidang kehidupan dan penghidupan. Oleh karena itu, hakhakpenyandang disabilitas harus dipenuhi agar dapat melaksanakan aktivitas tanpa adanya hambatan sebagaimana manusia seutuhnya tanpa kekuranganapapun. ${ }^{213}$

Menurut Pasal 1 ayat (1) Undang-Undang Nomor 8 Tahun 2016 tentang Penyandang Disabilitas, yaitu setiap orang yang mengalami keterbatasan fisik, intelektual, mental, dan/atau sensorik dalam jangka waktu lama yang dalam

${ }^{211}$ Lukman Arake.Islam dan Konseptualisasi Politik Kaum Minoritas.(Cet. I; Yogyakarta :Prudent Media. 2012). h. 3-4.

${ }^{212}$ Arrista Trimaya, "Upaya Mewujudkan Penghormatan, Perlindungan, dan Pemenuhan Hak Penyandang Disabilitas Melalui Undang-Undang Nomor 8 Tahun 2016 tentang Penyandang Disabilitas", Jurnal Legislasi Indonesia, Vol. 13 No. 04 - Desember 2016, h. 402.

${ }^{213}$ Maria Desti Rita, "Peran Komisi Pemilihan Umum Dalam Sosialisasi Pemilihan Umum Kepala Daerah Kepada Penyandang Disabilitas Dikota Bandar Lampung." (Skripsi, Fakultas Keguruan Dan Ilmu Pendidikan, Jurusan Pendidikan Ilmu Pengetahuan Sosial, Program Studi Pendidikan Pancasila Dan Kewarganegaraan, Universitas Lampung, 2016), h. 49. 
berinteraksi dengan lingkungan dapat mengalami hambatan dan kesulitan untuk berpartisipasi secara penuh dan efektif dengan warga negara lainnya berdasarkan kesamaan hak. ${ }^{214}$

Menurut Pasal 13 Undang-Undang Nomor 8 Tahun 2016 tentang Penyandang Disabilitas menyebutkan bahwa hak-hak politik bagi penyandang disabilitas meliputi: Hak memilih dan dipilih dalam jabatan publik.Menyalurkan aspirasi politik baik tertulis maupun lisan.Memilih partai politik atau individu yang menjadi peserta dalam pemilihan umum.Membentuk, menjadi anggota dan/atau pengurus organisasi masyarakat dan/atau partai politik.Membentuk danbergabung dalam organisasi penyandang disabilitas dan untuk mewakili penyandang disabilitas pada tingkat lokal, nasional, dan internasional.Berperan serta secara aktif dalam sistem pemilihan umum pada semua tahapan dan/atau bagian penyelenggaraan.Memperoleh aksesibilitas pada sarana dan prasaranapenyelenggaraan pemilihan umum, pemilihan Gubernur, Bupati/Walikota, dan pemilihan Kepala Desa. Serta memperoleh pendidikan politik. $^{215}$

Menurut Pasal 5 Undang-Undang Nomor 7 Tahun 2017 tentang Pemilihan Umum menyebutkan bahwa Penyandang Disabilitas yang memenuhi syarat mempunyai kesempatan yang sama sebagai pemilih, sebagai calon anggota DPR, sebagai calon anggota DPD, sebagai calon Presiden/Wakil Presiden, sebagai calon anggota DPRD, dan sebagai Penyelenggara Pemilu. ${ }^{216}$

\footnotetext{
${ }^{214}$ Republik Indonesia,Undang-Undang Republik Indonesia Nomor 8 Tahun 2016 tentang Penyandang Disabilitas, Pasal 1, ayat (1).

${ }^{215}$ Republik Indonesia,Undang-Undang Republik Indonesia Nomor 8 Tahun 2016 tentang Penyandang Disabilitas, Pasal 13.

${ }^{216}$ Republik Indonesia,Undang-Undang Republik Indonesia Nomor 7 Tahun 2017 tentang Pemilihan Umum, Pasal 5.
} 
Sebagai negara yang menganut sistem demokrasi, Indonesia sudah semestinya membuka ruang seluas-luasnya bagi masyarakat termasuk penyandang disabilitas untuk ikut berpartisipasi dalam ranah politik termasuk ikut serta dalam sistem pemerintahan.Karena hak politik sebagai salah satu dari serangkaian hak yang juga dimiliki oleh setiap warga negara termasuk penyandang disabilitas, karena memiliki arti penting bagi keberlangsungan dari perlindungan HAMyang berlaku di Indonesia.Ruang lingkup dari hak-hak politik sejatinya sangat luas, akan tetapi secara signifikan tingkat penyaluran hak politik penyandang disabilitas sangat terlihat dalam proses pemilihan umum. Oleh karena itu, Komisi Pemilihan Umum sebagai penyelenggara pemilu menjamin terpenuhinya hak politik setiap warga negara tanpa terkecuali baik itu penyandang disabilitas dalam pelaksanaan pemilihanumum. ${ }^{217}$

Pemilihan umum merupakan suatu sarana bagi masyarakat untuk ikut berpartisipasi dalam memberikan suaranya guna memilih wakil rakyat, serta merupakan bukti adanya upaya untuk mewujudkan demokrasi. ${ }^{218}$

Untuk menjamin terselenggaranya pemilihan umum yang luber dan jurdil diatur dalam Pasal 22E ayat (5) Undang-Undang Dasar 1945 menentukan bahwa, Pemilihan umum diselenggarakan oleh suatu Komisi Pemilihan Umum yang bersifat nasional, tetap, mandiri. ${ }^{219}$

${ }^{217}$ Mugi Riskiana Halalia, "Pemenuhan Hak Penyandang Disabilitas Sesuai dengan UndangUndang Nomor. 8 Tahun 2016 tentang Penyandang Disabilitas Oleh Komisi Pemilihan Umum (KPU) Kota Yogyakarta",,(Skripsi, Fakultas Syari'ah dan Hukum, Program Studi Ilmu Hukum, Universitas Islam Negeri Sunan Kalijaga Yogyakarta, 2016), h.3-4.

${ }^{218}$ Muhadam Labolo dan Teguh Ilham, Partai Politik dan Sistem Pemilihan Umum Di Indonesia Teori, Konsep dan Isu Strategis, (Cet. I; Jakarta :RajaGrafindo Persada, 2015), h.50.

${ }^{219}$ Republik Indonesia. Undang-Undang Dasar Tahun 1945, Pasal 22E ayat (5). 
Komisi Pemilihan UmumKabupaten Bone, sebagai lembaga penyelenggaraan pemilihan umum yang berkedudukan di Kota Watampone mengemban tugas untuk secara langsung menyelenggarakan pemilu mulai dari tahap persiapan hingga pelaksanaan pemilu. Maka dari itulah, Komisi Pemilihan Umum Kabupaten Bone berdasarkan fungsinyamemberikan pelayanan teknis dan administratif serta melakukan sosialisasi mengenai pemilu, juga berkewajiban melakukanpemenuhan hak politik masyarakat dalam pemilu sebagaimana kewenangannya sebagai penyelenggara pemilu di wilayah Kabupaten Bone. ${ }^{220}$

Pada Tahun 2015data yang diperoleh dariKetua PPDI Bone. A. Takdir. Menyebutkan dalam catatan Persatuan Penyandang Disabilitas Indonesia (PPDI) Bone, berjumlah6.383 orang.Yang terdiri dari usia di bawah 15 tahun laki-laki 295 dan perempuan 199. Untuk usia 15-44 tahun laki-laki 1.325 orang dan perempuan 957. Usia 45-59 tahun laki-laki 796 dan perempuan 736. Usia 60 keatas laki-laki 889 orang dan perempuan 1.186 .221

Sementara di Tahun 2019 data yang diperoleh langsung dari Kantor Komisi Pemilihan Umum Kabupaten Bone. Jumlah penyandang disabilitas yang terdaftar sebagai pemilih dalam Daftar Pemilih Tetap (DPT) 2019 yaitu: Tuna Daksa 418 orang, Tuna Netra 396 orang, Tuna Rungu/Wicara 409 orang, Tuna Grahita 204 orang, Disabilitas lainnya 264 orang.Jumlah keseluruhan Penyandang Disabilitas yang terdaftar sebagai Pemilih Tetap di DPT 1.691 orang. ${ }^{222}$

${ }^{220}$ Komisi Pemilihan Umum Kabupaten Bone. InfoPemiluKomisiPemilihanUmum Diakses, http://Infopemilu.kpu.go.id/pilkada/pemilih/dps/1/sulawesi\%20selatan/bone.25 November 2018.

${ }^{221}$ Andi Takdir, Ketua Persatuan Penyandang Disabilitas Indonesia (PPDI) Bone, wawancara oleh penulis di Kusuka Jl. Merdeka, 9 Agustus 2019.

${ }^{222}$ Resmiati, Kasubag Program dan Data Komisi Pemilihan Umum Kabupaten Bone, observasidata oleh penulis di Kantor Komisi Pemilihan Umum Kabupaten Bone, 20 juni 2019. 
Berdasarkan data diatas dapat diketahui bahwa jumlah Penyandang Disabilitas Tahun 2015 di KabupatenBone yang berusia 15-60 Tahun berjumlah 6.383orang, sementara di Tahun 2019 yang berhasil terdaftar sebagai pemilih tetap di pemilihan umum hanya 1.691 orang,artinyamasih banyak penyandang disabilitas di Kabupaten Bone yang belum didata dan terdaftar sebagai pemilih.Haltersebut dikarenakankurangnya informasi, sosialisasi dan fasilitas yang tersedia bagi penyandang disabilitas pada pemiluuntuk ikut berpartisipasi dalam menggunakan hak pilihnya.Oleh karena itu, KPU Kabupaten Bone sebagai pelaksana pemilihan umum sebaiknya melaksanakan pemenuhan hak politik penyandang disabilitas. Untuk itu perlu dilakukan penelitian yang berjudul"Peran Komisi Pemilihan Umum (KPU) Kabupaten Bone dalam Pemenuhan Hak Politik Penyandang Disabilitas di Pemilihan Umum Tahun 2019". Berdasarkan latar belakang masalah diatas, maka dirumuskan permasalahan sebagai berikut Bagaimana peranKomisi Pemilihan Umum (KPU) Kabupaten Bone dalam pemenuhan hak politikpenyandang disabilitas dipemilihan umum Tahun 2019 dan Apa kendala yang dihadapi Komisi Pemilihan Umum (KPU) Kabupaten Bone dalam pemenuhan hak pilih penyandang disabilitas pada Tahun 2019.

\section{TINJAUAN PUSTAKA}

Tinjauan pustaka berisi tentang uraian sistematis mengenai hasil-hasil penelitian yang pernah dilakukan sebelumnya oleh peneliti terdahulu yang mempunyai keterkaitan dengan penelitian yang akan dilakukan.Adapun penelitian yang memiliki relevansidengan judul penulis, sebagai berikut: 
Pertama,Skripsi yang ditulis oleh Maria Desti Rita, mahasiswa Universitas Lampung, berjudul Peran Komisi Pemilihan Umum Dalam Sosialisasi Pemilihan Umum Kepala Daerah Kepada Penyandang Disabilitas Di kota Bandar Lampung. Dalam penelitian ini merupakan hasil penelitian deskriptif kualitatif dengan subjek penelitian KomisionerKPU, Pusat Pemilihan Umum Akses Penyandang Cacat (PPUA Penca) dan Penyandang Disabilitas. Hasil penelitian ini menunjukkan masih terdapat penyandang disabilitas yang tidak terdaftar dalam DPT (Daftar Pemilih Tetap) pelaksanaan sosialisasi hanya dilakukan pada Penyandang Disabilitas yang tergabung dalam organisasi atau kelompok Penyandang Disabilitas. ${ }^{223}$

Kedua, Skripsi yang ditulis Mugi Riskiana Halalia, mahasiswa Universitas IslamNegeri Sunan Kalijaga Yogyakarta, berjudulPemenuhan Hak Penyandang Disabilitas Sesuai dengan Undang-Undang Nomor8 Tahun 2016 tentang Penyandang Disabilitas Oleh Komisi Pemilihan Umum (KPU) Kota Yogyakarta. Dalam penelitian ini merupakan hasil penelitian lapangan yang bersifat deskriptif kualitatif dengan hasil penelitian yang diperoleh dari KPU Kota Yogyakartatelah melakukan upaya-upaya pemenuhan hak politik bagi masyarakat penyandang disabilitas di Kota Yogyakarta dalam penyelenggaraan pemilihan umum. Upayaupaya KPU Kota Yogyakartadalam rangka melakukan pemenuhan hak penyandang disabilitas dalam pemilihan umum diantaranya, melakukan pemaksimalan pendataan pemilih terhadap penyandang disabilitas, memberikan sosialisasi mengenai kesamaan

\footnotetext{
${ }^{223}$ Maria Desti Rita, "Peran Komisi Pemilihan Umum Dalam Sosialisasi Pemilihan Umum Kepala Daerah Kepada Penyandang Disabilitas Di kota Bandar Lampung”, (Skripsi, Fakultas Keguruan Dan Ilmu Pendidikan, Jurusan Pendidikan Ilmu Pengetahuan Sosial, Program Studi Pendidikan Pancasila Dan Kewarganegaraan, Universitas Lampung, 2016).
} 
hak politik bagi penyandang disabilitas dan pelayanan terhadap penyandang disabilitas dalam pemilihan umum dengan menjunjung tinggi nilai-nilai kesetaraan. ${ }^{224}$

Dari deskripsi diatas jelas bahwa fokus masalah yang akan penulis bahas adalah"Peran Komisi Pemilihan Umum (KPU)Kabupaten Bone dalamPemenuhan Hak Politik Penyandang Disabilitas di Pemilihan Umum Tahun 2019”. Berbeda dengan penelitian sebelumnya. Dalam penelitian ini penulis lebih menekankan tentang peran komisi pemilihan umum dalam pemenuhan hak politik penyandang disabilitas dan kendala yang dihadapi komisi pemilihan umum dalam melaksanakanpemenuhan hak pilih penyandang disabilitas khususnya di Kabupaten Bone pada tahun 2019.

\section{METODE PENELITIAN}

Sebagaimana diketahui bahwa karya ilmiah selalu ditopang oleh beberapa metode baik dari pengumpulan data maupun dari pengolahannya seperti dalam penyusunan skripsi ini dipergunakan sebagai berikut:

1. Jenisdan Pendekatan Penelitian

a. Jenis Penelitian

Jenis penelitian yang dilakukan oleh penulis adalah penelitian lapangan (field research), yaitu data utama diperoleh dari peneliti sendiri yang secara langsung mengumpulkan informasi yang didapat dari responden terkait dengan

\footnotetext{
${ }^{224}$ Mugi Riskiana Halalia, "Pemenuhan Hak Penyandang Disabilitas Sesuai dengan UndangUndang Nomor. 8 Tahun 2016 tentang Penyandang Disabilitas Oleh Komisi Pemilihan Umum (KPU) Kota Yogyakarta", (Skripsi, Fakultas Syari'ah dan Hukum, Program Studi Ilmu Hukum, Universitas Islam Negeri Sunan Kalijaga Yogyakarta, 2016).
} 
peran Komisi Pemilihan Umum(KPU) Kabupaten Bone dalam pemenuhan hak politik penyandang disabilitas di pemilihan umum tahun 2019.

b. Pendekatan Penelitian

Penelitian yang dilakukan oleh penulis menggunakan pendekatan yaitu:

1) Pendekatan yuridis normatif adalah penelitian yang mengacu pada norma hukum yang terdapat dalam peraturan perundang-undangan dan putusan pengadilan serta norma-norma yang hidup dan berkembang dalam masyarakat. ${ }^{225}$

2) Pendekatan yuridis empiris adalah penelitian yang dilakukan dengan pendekatan pada realitas hukum dalam masyarakat. ${ }^{226}$

Kedua pendekatan di atas digunakan untuk mengambarkan bagaimana peran Komisi Pemilihan Umum (KPU) Kabupaten Bone dalam pemenuhan hak politik penyandang disabilitas di pemilihan umum tahun 2019.

\section{Lokasi Penelitian}

Adapun yang menjadi titik fokus dalam penelitian ini sebagai lokasi penelitianadalah Kantor Komisi Pemilihan Umum Kabupaten Boneterletak di Jalan Jenderal Gatot Subroto, Biru,Tanete Riattangdan Persatuan Penyandang Disabilitas Indonesia (PPDI) Kabupaten Bone terletak di Jalan Sungai Musi, Kelurahan Watampone, Kecematan Tanete Riattang. Alasan peneliti memilih Dua lokasi penelitian ini karena KPU merupakan lembaga mandiri yang memiliki peran penting terhadap masyarakatdalam Pemilu. sedangkan PPDI

${ }^{225}$ Zainuddin Ali, Metode Penelitian Hukum (Cet. V; Jakarta: Sinar Grafika, 2014), h. 105.

${ }^{226}$ Syahruddin Nawawi, Penelitian Hukum Normatif Versus Penelitian Hukum Empiris (Ed. 2, Cet. 2; Makassar: PT Umitoha Ukhuwah Grafika, 2013), h. 8. 
merupakan organisasi yang menaungi penyandang disabilitas di Kabupaten Bone.

3. Data dan Sumber Data

Data adalah segala keterangan (informasi) mengenai segala hal yang berkaitan dengan tujuan penelitian. Data kualitatif adalah data yang diperoleh dari berbagai sumber data. Sumber data dalam penelitian adalah subjek dari mana data diperoleh. ${ }^{227}$ Adapun yang menjadi sumber data dalam penelitian ini adalah sebagai berikut:

a. Data primer

Merupakan data yang diperoleh langsung dari sumbernya baik melalui wawancara, observasi, maupun laporan dalam bentuk dokumen tidak resmi yang kemudian diolah oleh peneliti. ${ }^{228}$ Data primer dalam penelitian ini diperoleh langsung dari lokasi penelitian yaitu Kantor Komisi Pemilihan Umum Kabupaten Bone dan PPDI Bone.Seperti wawancara secara langsung dengan pihak-pihak yang berhubungan dengan penelitian.

b. Data sekunder

Merupakan data penunjang yang keberadaannya hanya digunakan untuk memperkuat, melengkapi, atau memperkuat data primer. $^{229}$ Data sekunder berupa buku-buku atau literatur atau peraturan perundang-undangan serta data/dokumen lainnya yang berkaitan dengan masalah yang akan diteliti. Data

227 Suharamis Arikunto, Penelitian Suatu Pendekatan Praktek (Cet. XII; Jakarta: Rineka Cipta, 2002), h. 107.

${ }^{228}$ Zainuddin Ali, Metode Penelitian Hukum. (Cet. V; Jakarta: Sinar Grafika, 2014), h.106.

229 Nanang Martono, Metode Penelitian Sosial Konsep-konsep Kunci (Cet. I; Jakarta: Rajawali Pers, 2015), h. 67. 
sekunder diperoleh melalui studi pustaka dengan mengambil dasar-dasar teori dari berbagai buku, peraturan perundang-undangan maupun literature lainnya. Di dalam penelitian hukum, data sekunder mencakup: ${ }^{230}$

1) Bahan Hukum Primer

Merupakan bahan hukum yang mengikat, terdiri atas peraturan perundang-undangan yang berlaku atau ketentuan-ketentuan yang berlaku.

a. Undang-Undang Dasar Negara Republik IndonesiaTahun 1945.

b. Undang-Undang Nomor 4 Tahun 1997 tentang Penyandang Cacat.

c. Undang-Undang Nomor 39 Tahun 1999 tentang Hak Asasi Manusia.

d. Undang-Undang Nomor 8 Tahun 2016 tentang Penyandang Disabilitas.

e. Undang-Undang Nomor 7 Tahun 2017 tentang Pemilihan Umum.

2) Bahan Hukum Sekunder

Merupakan bahan hukum yang terdiri dari buku-buku dan tulisantulisan ilmiah hukumyang terkait dengan objek penelitian.atau seperti hasil-hasil penelitian, dan hasil karya dari kalangan hukum.

3) Bahan Hukum Tersier

Bahan hukum tersier merupakan bahan yang mendukung bahan hukum primer dan bahan hukum sekunder yang berasal dari kamus, ensiklopedia, majalah, surat kabar, dan sebagainya. ${ }^{231}$

${ }^{230}$ Soerjono Soekanto dan Sri Mamuji, Penelitian Hukum Normatif Suatu Tinjauan Singkat (Cet. V; Jakarta: PT RajaGrafindo Persada, 2001), h. 13.

${ }^{231}$ Zainuddin Ali, Metode Penelitian Hukum. (Cet. V; Jakarta: Sinar Grafika, 2014), h. 106. 


\section{Instrumen Penelitian}

Instrumen penelitian menunjuk berbagai peralatan yang digunakan selama melakukan penelitian.Dalam penelitian ini penulis menggunakan instrumen:

a. Dalam metode observasi maka instrumen yang digunakan adalahKamera.

b. Dalam metode wawancara maka instrumen yang digunakan penulis adalahdaftar pertanyaan/pedoman wawancara.

\section{Teknik Pengumpulan Data}

Teknik pengumpulan data ini berguna untuk mendapatkan data-data sebagaimana tersebut diatas digunakan, teknik pengumpulan data sebagai berikut:

a. Observasi, Observasi dapat diartikan sebagai pengamatan dan pencatatan secara sistematika terhadap unsur-unsur yang tampak dalam suatu gejala pada objek penelitian. ${ }^{232}$ Dalam penelitian ini observasi digunakan untuk memperkuat data, dengan mengamati aktivitas Komisi Pemilihan Umum Kabupaten Bone.

b. Wawancara merupakan suatu proses atau dialog secara lisan antara pewancara dan responden dengan tujuan untuk memperoleh informasi yang dibutuhkan oleh peneliti. ${ }^{233}$ Wawancara dilakukan dengan dua bentuk, yaitu wawancara terstuktur yaitu wawancara yang dilakukan

${ }^{232}$ S. Eko Putro Widoyoko, Teknik Penyusunan Instrumen, (Cet. I; Yogyakarta: Pustaka Pelajar, 2012),h. 46.

${ }^{233}$ Amiruddin dan Zainal Azikin, Pengantar Metode Penelitian Hukum (Cet. II; Jakarta: Rajawali Pers, 2004), h. 82. 
melalui pertanyaan-pertanyaan yang telah disiapkan. Sedangkan wawancara tak terstruktur adalah wawancara dilakukan apabila adanya jawaban berkembang diluar pertanyaan terstruktur namun tidak terlepas dari permasalahan peneliti. Wawancara difokuskankepada Komisioner KPU Kabupaten Bone dan Kasubag yang terkait dengan penelitian sertaKetua Persatuan Penyandang Disabilitas Indonesia (PPDI) Bone.

c. Dokumentasi,merupakan suatucara pengumpulan data yang dilakukan dengan menganalisis isi dokumen yang berhubungan dengan masalah yang diteliti.Metode ini digunakan untuk mengumpulkan data yang sudah tersedia dalam catatan dokumen, seperti konsep teori yang berkaitan denga variabel yang diteliti. ${ }^{234}$ Metode dokumentasi ini adalah metodeyang digunakan untuk mengabadikan proses dalam penelitian.

\section{Teknik Analisis Data}

Dalam menganalisis data, penulis menggunakan analisis data secara kualitatif, analisiskualitatif adalah penelitian yang berupaya menganalisis kehidupan sosial menggambarkan dunia sosial dari sudut pandang atau interpretasi individu (informan) dalam latar alamia. Dengan kata lain penelitian kualitatif berupaya menjelaskan bagaimana seorang individu, menggambarkan, atau memaknai dunia sosianya. ${ }^{235}$ Analisis data secara kualitatif dengantahapan sebagai berikut:

${ }^{234}$ S. Eko Putro Widoyoko, Teknik Penyusunan Instrumen, (Cet. I; Yogyakarta: Pustaka Pelajar, 2012),h. 49.

${ }^{235}$ Muhammad Teguh, Metodologi Penelitian Ekonomi Teori dan Aplikasi,(Jakarta: PT RajaGrafindo Persada, 2001), h. 134. 
a. Pengumpulan data lapangan yakni dengan mengumpulakan data yang ditemukan dilapangan yang merupakan data kasar.

\section{HASIL PENELITIAN DAN PEMBAHASAN}

\section{Kendala yang dihadapi Komisi Pemilihan Umum (KPU) Kabupaten Bone dalam}

\section{Pemenuhan Hak Pilih Penyandang Disabilitas pada Tahun 201}

Hak politik merupakan bagian dari Hak Asasi Manusia (HAM). Hak memberikan suara atau memilih (right to vote) merupakan hak dasar setiap individu atau warga negara yang harus dijamin pemenuhannyaoleh negara, tanpa ada diskriminasi mengenai ras, kekayaan, agama, dan keturunan. Negara harus memenuhi segala bentuk hak asasi setiap warga negara dalam Pemilihan Umum.Sementara hak pilih secara tersurat diatur dalam Undang-Undang Dasar Tahun 1945 mulai Pasal 27 ayat (1) dan (2); Pasal 28, Pasal 28D ayat (3), Pasal 28E ayat (3). Pengaturan ini menegaskan bahwa negara harus memenuhi hak asasi setiap warga negaranya, khususnya dalam keterlibatannya di pesta demokrasi yang meliputi Pemilihan Umum (Pemilu), Pemilihan Presiden (Pilpres) dan Pemilihan Kepala Daerah (Pilkada). ${ }^{236}$

Pemilihan umum merupakan suatu sarana bagi masyarakat untuk ikut berpartisipasi dalam memberikan suaranya guna memilih wakil rakyat, serta merupakan bukti adanya upaya untuk mewujudkan demokrasi. ${ }^{237}$

Untuk menjamin terselenggaranya pemilihan umum yang luber dan jurdil diatur dalam Pasal 22E ayat (5) Undang-Undang Dasar 1945 menentukan bahwa,

\footnotetext{
${ }^{236}$ Dakta.com, saduddin. Politik dan Pemerintahan. "Pengaturan Hak Politik Warga Negara”.Diakses,Http://www.dakta.com/news/1949/pengaturan-hak-politik-warga-negara. 10 Agustus 2019.

${ }^{237}$ Muhadam Labolo dan Teguh Ilham, Partai Politik dan Sistem Pemilihan Umum Di Indonesia Teori, Konsep dan Isu Strategis, (Cet. I; Jakarta :RajaGrafindo Persada, 2015), h.50.
} 
Pemilihan umum diselenggarakan oleh suatu Komisi Pemilihan Umum yang bersifat nasional, tetap, mandiri. ${ }^{238}$

Dalam pemenuhan hak pilih penyandang disabilitas terdapat beberapa kendala yang dihadapi Komisi Pemilihan Umum Kabupaten Bone diantaranya :

1) Keterbatasan sosialisasi kepada penyandang disabilitas.

Keterbatasan sosialisasi kepada penyandang disabilitas merupakan kendala yang dihadapi KPUKabupaten Bone.

Berdasarkan wawancara peneliti dengan Harmita. S.Si. Devisi Umum dan Keuangan Logistik di Kantor Komisi Pemilihan Umum Kabupaten Bone. Mengenai sosialisasi, menjelaskan bahwa:

"Sosialisasi yang kami lakukan kepada teman-teman penyandang disabilitas sudah kami lakukan namun cakupan sosialisasi hanya sampai diteman-teman disabilitas yang tergabung dalam organisasi tersebutbelum sampai ke daerahdaerah terpencil.Komisi Pemilihan Umum (KPU) Kabupaten Bone terus meningkatkan sosialisasi dengan membentuk basis yang namanya basis Relawan Demokrasi dimana tugasnya memberikan sosialisasi kepada masyarakat seperti yang dilakukan di daerah Lonrae, Palattae, dan beberapa wilayah lain di Kabupaten Bone". ${ }^{239}$

Berdasarkan wawancara di atasdapat disimpulkan bahwa sosialisasi yang dilakukanKPUKabupaten Bone sudah berjalan tetapi belum maksimal.KPU Kabupaten Bone perlu mengupayakan sosialisasi supayasampai ke daerah-daerah terpencil.Sehingga penyandang disabilitas yang tak terakses bisa mendapat informasi mengenai pemilu.

\footnotetext{
${ }^{238}$ Republik Indonesia. Undang-Undang Dasar Tahun 1945, Pasal 22E ayat (5).

${ }^{239}$ Harmita, Devisi Umum dan Keuangan Logistik, wawancara oleh penulis di Kantor Komisi Pemilihan Umum Kabupaten Bone.6 Agustus 2019. 
2) Kendala data penyandang disabilitas yangbelum akurat.

Data penyandang disabilitas yang belum akurat merupakan kendala yang dihadapi Komisi Pemilihan UmumKabupaten Bone dalam pemenuhan hak pilih penyandang disabilitas.

Berdasarkan wawancara peneliti dengan Harmita. S.Si. Devisi Umum dan Keuangan Logistik Komisi Pemilihan Umum Kabupaten Bone, menjelaskan bahwa :

"Kendala yang dihadapi Komisi Pemilihan Umum Kabupaten Bone adalah kendala dibidang pendataan.Kami hanya bisa mendata beberapa penyandang disabilitas yang tergabung dalam organisasi yang ada di Kabupaten Bone.Dimana data yang kami punya hanya terbatas diperoleh dari data pemilih tahun sebelumnya". ${ }^{240}$

Hal senadapun disampaikan olehKasubag Program dan Data. Resmiati. S.E,

M.Si. mengungkapkan bahwa :

"Kendala dalam pendataan yang dilakukan oleh Komisi Pemilihan Umum (KPU) Kabupaten Bone adalah hanya bisa mendata beberapa penyandang disabilitas yang tergabung dalam organisasi tertentu yang ada di Kabupaten Bone sehingga menyulitkan kami mendata penyandang disabilitas yang ada di pelosok kelurahan/desa di Kabupaten Bone". ${ }^{241}$

Berdasarkan hasil wawancara penelitidapat disimpulkan bahwa kendala Komisi Pemilihan Umum (KPU) Kabupaten Bone adalah data pemilih penyandang disabilitas yang digunakan masih data pemilih tahun sebelumnya. Sehingga banyak penyandang disabilitas belum terdata.Peran Pemerintah Daerah Kabupaten Bone juga dibutuhkan untuk melakukan pendataan supaya ada data baru yang akurat mengenai penyandang disabilitas sehingga memudahkan KPU Kabupaten Bone dalam mendata pemilih disabilitas.

\footnotetext{
${ }^{240}$ Harmita, Devisi Umum dan Keuangan Logistik, wawancara oleh penulis di Kantor Komisi Pemilihan Umum Kabupaten Bone.6 Agustus 2019.

241 Resmiati, Kasubag Program dan Data, wawancara oleh penulis di Kantor Komisi Pemilihan Umum Kabupaten Bone.6 Agustus 2019.
} 
3) Kendala fasilitas/pelayanan yang ada di Tempat Pemungutan Suara (TPS).

Fasilitas/pelayanan merupakan kendala dalam pemenuhan hak pilih karena masih didapat ketidak tersediaan alat bantu di TPSuntuk penyandang disabilitas. Komisi Pemilihan Umum Kabupaten Bone sudah mengusahakan pelayanan kepada penyandang disabilitas namun belum maksimal.

Berdasarkan wawancara peneliti denganHarmita. S.Si. Devisi Umum dan Keuangan Logistik, mengenai pelayanan.Menjelaskan bahwa:

"Mengenai pelayanan kami sudah berikan dan kami penuhi. Seperti kami siapkan surat suara braile untuk tunanetra diTPS sementara untuk RS (Rumah Sakit) kami sediakan TPS khusus seperti yang dilakukan di Rutan (Rumah Tahanan)". ${ }^{242}$

Berdasarkan wawancara di atas dapat disimpulkan bahwa pelayanan sudah diberikan secara maksimal seperti penyediaan alat bantu huruf Braile timbul untuk tunanetra, akan tetapi pemberian alat bantu Braile tersebut belum merata disiapkan disetiap TPS. Padahal alat tersebut sangat membantu disabilitas tunanetra dalam memberikan hak suaranya.

Selain itu peneliti juga mewawancaraiKetua Persatuan Penyandang Disabilitas Indonesia (PPDI) Bone mengenai fasilitas/pelayanan yang diberikan kepada penyandang disabilitas. Andi Takdir menjelaskan bahwa :

"Pelayanannya sekarang lumayan bagus dibanding tahun kemarin seperti adanya pelayanan alat bantu untuk teman-teman disabilitas tunanetra yaitu alat bantu huruf Braile untuk surat suara timbul. Walaupun tidak semua TPS menyediakan Brailesesuai dengan jumlah disabilitas tunanetra di TPS tersebut. Namun sebagian teman-teman sudah ada yang menggunakannyajadi, perlu ada tambahan alat bantu huruf Braile tersebut pada setiap TPS tertentu". 243

\footnotetext{
${ }^{242}$ Harmita, Devisi Umum dan Keuangan Logistik, wawancara oleh penulis di Kantor Komisi Pemilihan Umum Kabupaten Bone.6 Agustus 2019.

${ }^{243}$ Andi Takdir, Ketua Persatuan Penyandang Disabilitas Indonesia (PPDI) Bone, wawancara oleh penulis di Kusuka Jl. Merdeka, 9 Agustus 2019.
} 
Berdasarkan hasil wawancara peneliti di atas menunjukkan bahwa pelayanan yang diberikan kepada penyandang disabilitas sudah lumayan terpenuhi tetapi belum maksimal. Pemberian pelayanan tersebut dapat dilihat dari alat bantu Braile yang belum merata disiapkan disetiap TPS. KPU Kabupaten Bone sebagai penyelenggara pemilu setidaknya menyediakan alat bantu tersebut agar penyandang disabilitas bisa memberikan hak suaranya.

Peneliti juga mewawancarai salah satu penyandang disabilitas yang ikut berpartisipasi di pemilihan umum tahun 2019 mengenai fasilitas dan pelayanan khusus yang diberikan kepadanya. A. Abd. Bashir (Tunadaksa) Guru Mengaji di Btn Timurama 2. Mengatakan bahwa :

"Fasilitas dan pelayanannya Alhamdulillah sudah berjalan baik dibandingkan tahun lalu fasilitas yang diberikan untuk saya di pencoblosan seperti biasa saja pada umumnya. Sedangkan fasilitas yang diberikanteman-teman disabilitas tunanetra diberikan surat suara khusus dengan huruf Braile tetapi belum merata dan untuk teman-teman tunarungu tidak disiapkan fasilitas bahasa isyarat mungkin itu saja kekurangannya, sehingga teman-teman tunarungu mendapat hak pilihnya dengan cara pendampingan dalam memilih". ${ }^{244}$

Berdasarkan wawancara peneliti dengan A. Abd. Bashir menunjukkan bahwa KPU Kabupaten Bone telah memberikan fasilitas/pelayanan baik kepadanya di pemilihan umum tahun 2019. Dimana disabilitas tunanetra mendapat kertas suara Braile tetapi belum terlalu merata dan untuk disabilitas tunarungu belum mendapat bantuan bahasa isyarat tetapi mendapat pendampingan di pemilihan umum.

Dari hasil wawancara peneliti dapat disimpulkan secara keseluruhan mengenai kendala dalam pemenuhan hak pilih di Pemilihan umum tahun 2019 adalah :

1) Keterbatasan sosialisasi kepada penyandang disabilitas,

${ }^{244}$ A. Abd. Bashir. (Tunadaksa) Guru Mengaji di Btn Timurama 2.7 Agustus 2019. 
2) Kendala data penyandang disabilitas yang belum akurat, dan

3) Kendala Fasilitas/Pelayanan yang ada di Tempat Pemungutan Suara (TPS).

Ketiga ini merupakan kendala yang dihadapi Komisi Pemilihan Umum (KPU) Kabupaten Bone dalam pemenuhan hak pilih penyandang disabilitas di Pemilihan Umum Tahun 2019.

Komisi Pemilihan Umum (KPU) Kabupaten Bone Sebagai penyelenggara pemilihan umum seharunya memberikanpelayanan sosialisasi kepadamasyarakat. Sebagaimana yang terdapat pada Pasal 18J. "Menyosialisasikan penyelenggaraan pemilu dan/atau/ yang berkaitan dengan tugas dan wewenang KPU Kabupaten/Kota kepada masyarakat". Undang-Undang Nomor 7 Tahun 2017 tentang Pemilihan umum, supaya masyarakat mendapatkan sosialisasi dan informasi mengenai pemilihan umum. Sehingga hak pilihnya di pemilihan umum bisa tersalurka. ${ }^{245}$

Harmita.S.Si. Devisi Umum dan Keuangan Logistik. Mengungkapkan harapan kedepannya untuk Komisi Pemilihan Umum (KPU) Kabupaten Bone dalam pemenuhan hak pilih penyandang disabilitas.

"Harapan kami kedepannya lebih banyak informasidata yang akurat mengenai penyandang disabilitas sehingga banyak penyandang disabilitas ikut dalam pemenuhan hak pilihnya dan juga banyak melibatkan lembagabukan dari Komisi Pemilihan Umum saja tetapi dari calon-calon anggota legislatif, lembaga-lembaga yang melakukan pendataan,Kelurahan/Desa serta dari Dinas Sosial Kabupaten Bone sehingga terkumpul data yang akurat. Dimana data itu nantinya memudahkan KPUmelakukan pendataan pemilih dan mendorong peningkatan partisipasi penyandang disabilitas dalam pemilihan umum kedepannya". ${ }^{246}$

\footnotetext{
${ }^{245}$ Republik Indonesia. Undang-Undang Nomor7 Tahun 2017 tentang Pemilihan Umum. Pasal 18J.

${ }^{246}$ Harmita, Devisi Umum dan Keuangan Logistik, wawancara oleh penulis di Kantor Komisi Pemilihan Umum Kabupaten Bone.6 Agustus 2019.
} 
Adapun harapan dari Ketua Persatuan Penyandang disabilitas Indonesia (PPDI) Bone. Andi Takdir, Mengatakan bahwa:

"Harapan kami supaya kedepannya teman-teman penyandang disabilitas lebih diperhatikan lagi terkhusus tunarungu mendapat bahasa isyaratdan juga tunadaksa beratikut dilibatkandalam pemilihan umum dimana tidak bisa datang di TPS setidaknya dari petugas bisa dibawakan kertas suara kerumahnya supaya tidak hilang hak suaranyadipemilihan umum". ${ }^{247}$

\section{PENUTUP}

\section{Kesimpulan}

Berdasarkan hasil penelitian yang telah dilakukan penulis bahwa peran Komisi Pemilihan Umum (KPU) Kabupaten Bone sebagai penyelenggaa Pemilihan Umum di wilayah Kota Watampone telah melakukan peranuntuk memenuhi hak politik penyandang disabilitas dalam pemilihan umum. Peran KPU tersebut telah sesuai dengan Undang-Undang Nomor 7 Tahun 2017 tentang Pemilihan Umum dan pemenuhan hak-hak politik penyandang disabilitas yang telah diberikan sesuai dengan Undang-Undang Nomor 8 Tahun 2016 tentang Penyandang Disabilitas, meskipun peran Komisi Pemilihan Umum dan pemenuhan seluruh hak-hak politik penyandang disabilitas dalam pemilihan umum tersebut belum dapat dilakukan secara maksimal. Namun sejauh ini Komisi Pemilihan Umum Kabupaten Bone masih terus mengupayakan agar pemenuhan hak politik penyandang disabilitas dapat tersalurkan mulai dari hak memilihnya, pendataan pemilih penyandang disabilitas, pemberian fasilitas secara maksimalserta pelayanan aksebilitas yang baik.Hal lain juga yang dihasilkan dalam penelitian ini kurangnya kelengkapan data yang akurat mengenai penyandang disabilitas, meskipun pendataan belum memuaskan hati tetapi Komisi

\footnotetext{
${ }^{247}$ Andi Takdir, Ketua Persatuan Penyandang Disabilitas Indonesia (PPDI) Bone, wawancara oleh penulis di Kusuka Jl. Merdeka.9 Agustus 2019.
}

Jurnal Al-Dustur; VOLUME 2 NO 2, DESEMBER 2019 
Pemilihan Umum Kabupaten Bone terus melakukan pendataan pemilih disabilitas sehingga hak pilih penyandang disabilitas bisa terpenuhi dalam pemilihan umum.

1. Adapun kendala Komisi Pemilihan Umum (KPU) Kabupaten Bone dalam pemenuhan hak pilih penyandang disabilitas di pemilihan umum tahun 2019 yaitu, (a).Keterbatasan sosialisasi kepada penyandang disabilitas, (b).Kendala data Penyandang disabilitas yang belum akurat, dan (c).Kendala Fasilitas/Pelayanan yang ada di Tempat Pemungutan Suara (TPS)

\section{DAFTAR REFERENSI}

A. Ubaedillah, dan Abdul Rozak. Pendidikan Kewarganegaraan (Civic Education), Pancasila, Demokrasi, HAM, dan Masyarakat Madani. Cet. XI; Jakarta: Prenada Media Group, 2014.

Ali,Al-Jumanatul.Al-Quran dan Terjemahan. Jakarta: Departemen Agama Republik Indonesia, 2006.

Ali, Zainuddin. Metode Penelitian Hukum. Cet. V; Jakarta: Sinar Grafika, 2014.

Ali, Zainuddin. Sosiologi Hukum. Cet. VIII; Jakarta: Sinar Grafika, 2014.

Alwi, Hasan. Kamus Bessar Bahasa Indonesia. Jakarta: Balai Pustaka, 2002.

Amiruddin dan Asikin,Zainal. Pengantar Metode Penelitian Hukum. Cet. II; Jakarta: PT RajaGrafindo Persada, 2004.

Arake,Lukman. Islam dan Konseptualisasi Politik Kaum Minoritas.Cet. I; Yogyakarta : Prudent Media. 2012.

Arikunto, Suharamis.Penelitian Suatu Pendekatan Praktek. Cet. XII; Jakarta: Rineka Cipta, 2002.

Ash shiddieqh, T. Muhammad Hasby.Islam dan Hak Asasi Manusia. Semarang: PT. Pustaka Rizki Putra, 1999.

Hasan, Muhammad Tholchah. dkk. Metode Penelitian Kualitatif Tinjauan Teoritis dan Praktis. Cet. III; Surabaya: Visipress Media, 2009. 
Labolo, Muhadam.dan Ilham, Teguh.Partai Politik dan Sistem Pemilihan Umum Di Indonesia Teori, Konsep dan Isu Strategis. Cet. I; Jakarta: RajaGrafindo Persada, 2015.

Martono, Nanang. Metode Penelitian Sosial Konsep-konsep Kunci. Cet. I; Jakarta: Rajawali Pers, 2015.

Mana, H. Abdul.Politik Hukum: Studi Perbandingan Dalam Praktik Ketatanegaraan Islam dan Sistem Hukum Barat. Ed. 1, Cet, 1. Jakarta: Prenamedia Group, 2016.

Nawawi, Syahruddin. Penelitian Hukum Normatif Versus Penelitian Hu Empiris.Ed. 2, Cet. 2; Makassar: PT Umitoha Ukhuwah Grafika, 2013.

Reefani, Nur Kholis. Panduan Anak Berkebutuhan Khusus, Yogyakarta: Imperium. 2013.

Sutaryo. Dasar-Dasar Sosiologi.Cet. I; Jakarta: Rajawali Perss, 2004.

Soekanto, Soerjono dan Sri Mamuji. Penelitian Hukum Normatif Suatu Tinjauan Singkat. Cet. V; Jakarta: PT RajaGrafindo Persada, 2001.

Teguh, Muhammad. Metodologi Penelitian Ekonomi Teori dan Aplikasi, Jakarta: PT RajaGrafindo Persada, 2001.

Wursanto, Dasar-dasar Ilmu Organisasi. Ed II; CV. 1; Andi Offset: Yogyakarta, 2003.

Widoyoko, S. Eko Putro.Teknik Penyusunan Instrumen. Cet. I; Yogyakarta: Pustaka Pelajar, 2012. 